\title{
Teaching Perspectives of Pre-service Physical Education Teachers in Shanghai: A Pilot Study
}

\author{
Lijuan Wang \\ Department of Leisure Sports, Shanghai University of Sport \\ Changhai Road No 399, Yangpu District, Shanghai, China \\ E-mail:wlj711@yahoo.com.cn
}

Received: September 6, 2011

Accepted: October 24, $2011 \quad$ Published: January 1, 2012

doi:10.5539/ass.v8n1p209

URL: http://dx.doi.org/10.5539/ass.v8n1p209

The research is financed by Shanghai Municipal Education Commission (Project. No. 10sg48).

\begin{abstract}
The purpose of this study is to examine the teaching perspective of pre-service Physical Education teachers in Shanghai, China. The Teaching Perspectives Inventory instrument (Pratt, 1998) was used to collect data from 158 pre-service teachers. Descriptive data showed that pre-service teachers exhibited a common pattern of at least one or perhaps two dominant teaching perspectives. They attached importance to student affective development, but paid less attention to the change of society and student thinking. A series of univariate analyses of variance revealed that the scores of the female teachers on Nurturing were significantly higher than those of the male teachers. Although study levels had no significant effect on teaching perspectives of pre-service teachers, a slight increase in the mean scores of Transmission and Social Reform perspectives was observed in first-year to fourth year pre-service teachers. Finally, a significant correlation among several perspectives was observed. Using the findings as bases, we provide implication for the improvement of teaching perspectives.
\end{abstract}

Keywords: Pre-service physical education teachers, Teaching perspectives, Physical education innovation

\section{Introduction}

Numerous studies have revealed that teaching is a complex and challenging filed (e.g., Kent, 2000; Rust, 1994). In exploring the complexity of teaching, researchers have noted that beliefs and perspectives play a critical role because they are recognized as important mediators of teaching behaviours (McNeil, 1990). They form the rationales that determine, in part, how practical educational decisions are made by teachers (Eisner, 1992). Given the importance, a growing number of scholars have shifted their focus from instructional strategies and teaching behaviours to perspectives, beliefs or value orientation on teaching that prompt teachers to use instructional strategies and exhibit certain behaviours in recent years (Clarke \& Jarvis-Selinger, 2005; Jarvis-Selinger, Collins \& Pratt, 2007; Rovegno, 2003).

In the Physical Education (PE) domain, although the theoretical framework and curriculum provide general directions for teaching, freedom is provided to $\mathrm{PE}$ teachers to make a significant number of important educational decisions. These decisions include what content to teach, how to teach it, and the extent to which the content will be learned by students (Behets \& Vergauwen, 2004; Ennis \& Chen, 1995). Due to the common assumption that the decisions teachers made are based on a set of educational perspectives or value orientations (Eisner, 1992; Pajares, 1992), many researchers addressed the importance to study PE teachers' thinking and beliefs on teaching and have conducted a considerable amount of research on this issue (e.g., Behets, 2001; Behets \& Vergauwen, 2004; Ennis \& Chen, 1995; Solmon \& Ashy, 1995; Tsangaridou, 2008). Despite of this, Stran and Curtner-Smith (2009) revealed that very little work on pre-service teachers' perspective or beliefs on teaching has been carried out. To bridge research gaps, this study focused on pre-service teachers and adopted a theoretical framework on teaching perspectives (Pratt, 1992; Pratt \& Associates, 1998; Pratt, Collins, \& Selinger, 2001) and Teaching Perspective Inventory (TPI; Pratt \& Associates, 1998) to investigate pre-service teachers' perspectives on teaching. 


\section{Teaching Perspectives}

The theoretical framework of teaching perspectives has been described and investigated intensively by Pratt and his colleagues (Pratt, 1992; Pratt \& Associates, 1998; Pratt et al., 2001). Teaching perspective is defined by Pratt and Assocaites (1998) as what we "do as teachers and why we think such actions are worthy and justified" (Pratt \& Assocaites, 1998; p.10). Many researchers have attempted to conceptually define and empirically document teaching perspectives (e.g., Fox, 1983; Pratt, 1992). These studies have shown a surprisingly high level of correspondence in identifying qualitatively different perspectives. Pratt and associates (1998) reviewed thirteen relevant studies and found five substantively different views of teaching in higher education, namely, transmission, apprenticeship, developmental, nurturing, and social reform. Each perspective is further defined as:

(i)

Transmission perspective emphasizes that effective teaching requires a substantial commitment to the content or subject matter. According to this perspective, teachers' primary responsibility is to present the content accurately and efficiently and "good teachers take learners systematically through a set of tasks that lead to mastery of the content. They are clear and convey that enthusiasm to their students (Pratt et al., 2001, p.3)

(ii) Teaching from an Apprenticeship perspective is directly associated with real setting of application. It assumed that learning is facilitated when students "work on authentic tasks in real settings of application or practice...when both teaching and learning are rooted in the doing of work, not just in talking about it" (Pratt et al., 2001, p.3).

(iii) The Developmental perspective addressed that effective teaching must be planned and conducted "from the learner's point of view" (Pratt et al., 2001, p.4). Thus, teachers must understand how their learners think and reason about the content.

(iv) According to the Nurturing perspective, effective teaching is a long-term, hard, persistent effort to achieve that comes from the heart, as well as the head; hence, good teachers "care about their students, promote a climate of caring and trust, help people set challenging but achievable goals, and support learners' efforts as well as their achievements" (Pratt et al., 2001, p.4).

(v) From a social Reform perspective, effective teaching seeks to change society in substantive ways. Therefore, teachers should awaken students to "values and ideologies that lie hidden in texts and common practices [and] challenge the status quo to encourage students to consider the ways in which they and their [students] are positioned and constructed within particular discourses" (Pratt et al., 2001, p.4).

A few studies have been conducted to examine the teaching perspective of pre-service and in-service teachers using the Teaching Perspectives Inventory (TPI) in educational and PE research area (Courneya, Pratt, \& Collins, 2008; Clarke \& Jarvis-Selinger, 2005; Deggs, Matchtmes, \& Johnson, 2008; Ha, Butler, Pratt \& Collins, 2008; Jarvis-Selinger et al., 2007). Jarvis-Selinger et al. (2007) surveyed 356 pre-service teachers seeking secondary teaching certification. This group of pre-service teachers completed TPI on line. Findings revealed that Nurturing was the most dominant and Social Reform was the least dominant perspective among those participants involved in the study. Furthermore, results showed that perspectives on teaching vary across disciplinary majors. For example, Pre-service teachers preparing to teach in social studies, language arts and home and technical sciences were significantly higher on Social Reform higher than those in the life sciences or math/science. Pre-service teachers in both life sciences and math/sciences scored significantly higher on the Transmission perspective than did people in language arts, expressive arts, home and technical science. Meanwhile, gender differences were also found in this study, which is that women's Nurturing scores showed significantly higher than men's. The TPI was also used by Ha et al. (2008) to examine the beliefs, intentions and actions in teaching and the relationship between pre-service PE teachers' TGfU learning and teaching experience and their teaching perspective. Three cohorts of pre-service teachers $(\mathrm{N}=56)$ were surveyed in the study by Ha et al. The findings indicated that out of the scores on five perspectives, those of Nurturing scores were generally high for all three cohorts whereas Social Reform and Developmental scores were generally low. Moreover, their belief scores were also higher, although these Beliefs did not appear to translate clearly into Intention or Actions. Moreover, the study also revealed that pre-service teachers who had greater exposure to TGfU together with more actual teaching experiences had stronger teaching perspectives as well as stronger Beliefs, Intentions, and Actions over time. 


\section{China Context}

In recent years, the PE curriculum in China has undergone tremendous changes. The syllabus Program of Basic Education Curriculum Reform (trial) was issued in 2002. The objective of the new PE curriculum is to broaden the development of students from the skills domain alone to include the psychomotor, cognitive, and affective domains. Five issues, namely, the sports participation, technique development, physical and mental health, and social adaptability of students are addressed in the new curriculum (Chinese Ministry of Education, 2002). . In the meantime, the student-centered teaching is addressed in the new PE curriculum.

With the innovation of PE curriculum, many Chinese researchers suggested that the old teaching perspectives of PE teachers should be changed to be inline with the objectives of new PE curriculum in order to implement the new PE curriculum effectively (e.g., Shi \& Huang, 2006; Wang, 2004). For example, Shi and Wang (2006) suggested that PE teachers pay more attention to student creativity and problem solving. However, few studies have investigated the teaching perspectives of PE teachers in China using the survey or interview format. Furthermore, little is known about whether the teaching perspectives of PE teachers are consistent with the direction of the innovation of the PE curriculum. To these ends, a pilot survey was conducted in this study and aims to (i) examine the dominant teaching perspectives of pre-service teachers, (ii) explore the effects of gender and study levels of pre-service teachers on differences in teaching perspectives, and (iii) examine the correlations among the five teaching perspectives of pre-service teachers. The study is expected to provide direction and basis for the professional development of pre-service teachers, and offer support for the implementation of a new PE curriculum in China.

\section{Research Method}

\subsection{Participants and Procedures}

A cross-sectional research design was adopted by colleting TPI data from four pre-service teacher cohorts. A total of 158 PE majors at Shanghai University of Sport $(M=86, F=72)$ responded to this survey. The age of the respondents was between 17 and 23. They were composed of 4 cohorts: (1) The first group was 1st year student $(\mathrm{N}=48)$ who have not taken any pedagogical course and have no any experience of teaching. Thus, their teaching perspectives are based on their prior learning experience of PE as pupils at elementary and secondary schools; (2) The second group was 2nd year student ( $\mathrm{N}=38$ )who had completed two pedagogical course "Theory of Sport Pedagogy" and "Educational Theories", but had no any teaching experience; (3) The third group was 3nd year students ( $=34)$ who had completed the course of "Theory of Sport Pedagogy" and "Educational Theories" and also had no any teaching experience. However, they completed the other course "Elementary and Secondary School PE Pedagogy"; (4) The fourth group was 4th year students ( $N=36)$ who had fulfilled 4-month teaching experience at primary or secondary schools.

The survey was administered in the fourth quarter of 2010 in Shanghai. Surveys were distributed by PE faculty in each of their classes in three universities. Prior to the conduction of the survey, pre-service teachers were told not to complete the survey if they had received it in other classes. Pre-service teachers were assured that participation was voluntary and the confidentiality was guaranteed. And then, the Consent Form and the TPI were then distributed to the pre-service teachers who volunteered. The participants were read the instructions and then directed to complete the TPI together with brief demographic and background information (e.g., teaching or training experience, the pedagogical course they took, age, sex, and grade). The instrument was collected by the faculty immediately after each participant finished. After that, the information of each survey was filled into the online TPI by the primary investigator and a student research assistant.

\subsection{Instruments}

The TPI, which is a 45-item instrument, was adopted to examine the teaching perspectives. The 45 items in the instrument are grouped into three sets of 15 items and are related to the beliefs of teachers on the fundamental principles of teaching and learning, their intentions and how they organize the learning situation, and their actions within the teaching setting. These items yielded five perspectives on teaching from each pre-service teacher. A six-point rating scale that ranges from "strongly disagree" (1) and "strongly disagree" (6) or "never" (1) and "always" (6) was used. More than 3000 respondents from a wide range of professions have completed the TPI. The analyses of their responses confirmed that the five TPI scales have factorial integrity and demonstrate both test-retest and interitem reliability (Pratt and Collins, 2000). The TPI showed early internal consistency (Cronbach's alpha) averaging about 0.80 with smaller and homogeneous samples (Pratt \& Collins, 2000) and about 0.71 with the current large and heterogeneous groups. Test retest reliabilities were also calculated for a 182-person sub-sample of people who had taken the TPI more than once. Test retest reliabilities for each of the perspectives were Transmission $=0.81$, Apprenticeship $=0.88$, Developmental $=0.85$, Nurturing 
$=0.92$, Social Reform $=0.82$, with an overall reliability of 0.80 . For the current work, the TPI was translated into Chinese in accordance with the translation-back-translation procedure.

\subsection{Data Analysis}

Descriptive statistics was adopted to describe the teaching perspectives of the pre-service teachers. Statistical data were obtained by calculating the raw scores for each perspective (ranging from 9 to 45 points) and then comparing the means of each perspective score to determine perspective dominance. A perspective is considered dominant if its score is one or more standard deviations above the means across the five perspectives for each teacher, whereas a perspective is considered recessive if its score is one or more standard deviations below the means across the five perspectives for each person. The frequencies and percentages of each perspective were calculated for descriptive purposes. Furthermore, multivariate analysis of variance (MANOVA) was performed with the five teaching perspectives as dependent variables and demographic data (gender and study level) as factors to examine the main effects of the independent variables on teaching perspectives. For significant MANOVAs, univariate follow-ups were adopted to determine significant differences in the teaching perspectives as a function of gender and study levels. Finally, correlational procedures were used to test the relationships among the five teaching perspectives.

\section{Results and Discussion}

\subsection{Dominant and Recessive Teaching Perspectives}

As Table 1 suggests that of the 158 pre-service teachers involved in this study, 62 respondents $(39.2 \%)$ had a singularly dominant perspective, 80 respondents $(50.6 \%)$ had a combination of two dominant perspectives, and 16 respondents $(10.2 \%)$ had no dominant perspectives. Moreover, 65 respondents $(41.2 \%)$ had one perspective that was clearly recessive. Approximately 90 people $(56.9 \%)$ had no distinguishable low scores and only three respondents $(1.9 \%)$ had two such low-scoring perspectives. The pre-service teachers exhibited a common pattern of at least one or perhaps two dominant teaching perspectives and no distinguishable recessive perspective. These findings are different from those obtained by Deggas (2008), who noted that majority of pre-service teachers in the U.S only had one singular teaching perspective, indicating that the teaching perspectives of pre-service teachers in China may be more diversified than those of teachers in the U.S. On the other hand, the results of this study are consistent with the new concept of $\mathrm{PE}$, recently introduced in curriculum innovation in China. the traditional concept of PE was limited to fitness perspectives alone. In the beginning of 2000s this single vision of learning goals was broadened to the concept of fitness, health, cognitive and affection (Chinese Education Ministry, 2002). The new PE concept was introduced to pre-service teachers through various pedagogical courses included in PETE programme, which have effect on the development of pre-service teachers' teaching perspectives (Solmon \& Ashy, 1995).

Among all dominant teaching perspectives, Nurturing ranked the highest (51.3\%). By contrast, only 25 (15.8\%) and 22 (13.9\%) exhibited Developmental and Social Reform perspective as the dominant perspectives respective, which are the least frequently dominant perspective. Similarly, Development (13.9\%) and Social Reform (15.8\%) were the most commonly recessive among the five perspectives, whereas Apprenticeship was the least commonly recessive (1.9\%). These findings indicate that the pre-service teachers involved in this study strongly believed that "Effective teaching assumes that long-term, hard, persistent effort to achieve comes from the heart, as well as the head" and that they paid less attention to "changing society" and student thinking. These observations are partially in line with previous findings (Ha et al., 2008), which showed that Nurturing was the single most common dominant perspective and Social Reform is the least frequently dominant perspective for pre-service teachers in Hong Kong. This indicates that the teaching perspectives of pre-service teachers in common cultures are similar. On the other hand, the new PE curriculum emphasized the importance of affective development in students, an issue previously ignored. From this standpoint, the teaching perspective of pre-service teachers is consistent with the principles of PE innovation. However, the low scores for Development showed that teacher-centered strategies still dominate PE teaching in China. The new PE curriculum suggested that student-centered approach that characterized by active learning and student involvement be implemented in PE teaching. The findings of the current study revealed that this aspect of this concept has yet to be elaborated. Moreover, pre-service teachers did not assimilate Social Reform as the dominant perspective. This result is not surprising for pre-service teachers who lack teaching experience with actual settings as they still lack the capacity to recognize the connection between society and teaching.

\subsection{Gender Differences}

There were 72 female and 86 male participants who responded to the TPI. Results from the MANOVA indicated that there is significant differences in the five perspectives by gender, $\mathrm{F}=2.53, \mathrm{P}=0.04$. The follow-up univariate 
test results revealed that the Nurturing perspective contributed to the significant difference (See Table 2). The Nurturing scores for the female participants $(M=36.44, S D=3.30)$ were significantly higher $[F(1,156)=4.82, p$ $=.03]$ than those of the males $(\mathrm{M}=33.73, \mathrm{SD}=5.25)$, indicating that compared with their male contemporaries, female pre-service teachers were more concerned with student affective performance and tended to establish a learning environment that is based on care, encouragement, and trust. This is consistent with the literature on the feminization of teaching (Bradley, 1989) that has occurred in recent decades and where women are more sensitive and patient and therefore viewed as especially suitable for teaching (Johnson, 1989).

\subsection{Differences among Study Levels}

Pre-service teachers with different study levels showed a slightly different pattern in their teaching perspectives. Although results from the MANOVA indicated there were no significant differences in the five perspectives by teaching experience, $\mathrm{F}=2.06, \mathrm{P}=0.07$, the mean scores on Transmission and Social Reform perspectives increased from the first to the fourth year pre-service teachers (See Table 3). This indicates that a slight increase in the subject knowledge of pre-service teachers and a positive change in their attitude towards the "teaching changes society" perspective after completing a series of relevant pedagogical courses and gaining teaching experience. The research results in the present study proved the earlier findings that pedagogical courses in teacher education program had a positive impact on pre-service teachers' beliefs and value orientations (Ashy \& Humphries, 2000; Solmon \& Ashy, 1995; Timken \& Mars, 2009; Xiang, Lowy \& McBride, 2005). The findings are encouraging in light of the efforts of PE teacher educators to develop advocacy for quality PE pedagogical courses and teaching practicum among pre-service teachers.

\subsection{Correlation among the Five Perspectives}

The correlations among the five teaching perspectives for pre-service teachers are presented in Table 4 . The correlation matrix indicated a significant correlation $(.34, \mathrm{p}<0.05$ and $.77, \mathrm{p}<0.01)$ among Apprenticeship, and Development, and Social Reform. Additionally, a significant correlation was observed between Development and Nurturing $(0.61, \mathrm{p}<0.01)$. This indicates that pre-service teachers who believed that theory should be connected to practice tend to support the student-centered teaching style and the perspective that teaching changes society. Pre-service teachers with a student-centered teaching style also tend to support the perspective that teachers should be concerned with the affective development of students. The findings reflect that teaching perspectives influence one another and that these perspectives of do not exist independently. Thus, to improve the teaching perspectives of pre-service teachers, a comprehensive consideration of the five perspectives is needed.

\section{Conclusion and Implication}

The descriptive analysis of the teaching perspective profiles indicates that the teaching perspectives of pre-service teachers are transforming from a singular to a more diversified pattern. Furthermore, the majority of pre-service teachers tended to be concerned about the affective development of students but still adopted teacher-centreed instruction and did not support the viewpoint that teaching changes society. Therefore, we suggest that more training programs on the new PE curriculum be offered to pre-service teachers to enable them to gain a better understanding of student-centered teaching. More opportunities should be provided to pre-service teachers to afford them considerable exposure to society and help them improve their recognition of the connection between teaching and society.

A significant difference in the affective perspectives of male and female pre-service teachers was observed. However, although no significant differences in the five teaching perspectives were observed among four cohort pre-service teachers with different study years, a tendency for the Transmission and Social Reform perspectives to increase from the first to the fourth year pre-service teachers was found. This may be related to the pedagogical courses that they took and their teaching experiences. Therefore, we suggest that the pedagogical curriculum in PE departments in Shanghai be strengthened (for example, update teaching materials). Furthermore, more teaching opportunities should be offered to pre-service teachers to facilitate changes in their teaching perspectives.

The findings indicated a significant correlation among Apprenticeship, Development, and Social Reform, and between Development and Nurturing. Therefore, to promote the professional development of pre-service teachers, the comprehensive and similar development of all the five perspectives is needed.

\section{References}

Ashy, M. \& Humphries, C. A. (2000). Don't use balloons on windy days: Elementary education majors' perceptions of teaching elementary physical education. Action in Teacher Education, 22, 59-71. 
Behets, D. (2001). Value orientations of physical education preservice and inservice teachers. Journal of Teaching in Physical Education, 20, 144-154. [Online] Available: http://journals.humankinetics.com/jtpe-back-issues/JTPEVolume20Issue2January

Behets, D. \& Vergauwen, L. (2004). Value orientations of elementary and secondary physical education teachers in Flanders. Research Quarterly for Exercise and Sport, 75(2), 156-164.

Bradley, H. (1989). Men's work, women's work. Minneapolis: University of Minnesto Press.

Chinese Ministry of Education. (2002). Primary and Secondary Physical Education Curriculum Standard.

Clark, A. \& Jarvis-Selinger, S. (2005). What the teaching perspectives of cooperating teachers tell us about their advisory practices. Teaching and Teacher Education, 21, 65-78. [Online] Available: http://www.sciencedirect.com/science/journal/0742051X/21/1

Collins, J., Jarvis-Selinger, S. \& Pratt, D (under review). How do perceptions of teaching vary across disciplinary majors among students enrolled in teacher preparation? Academic Exchange Quarterly, (under review).

Courneya, C., Pratt, D. \& Collins, J. (2008). Through what perspective do we judge the teaching of peers. Teaching and Teacher Education, 24, 69-79. [Online] Available: http://www.sciencedirect.com/science/journal/0742051X/24/1

Deggs, D., Machtmes, K. \& Johnson, E. (2008). The significance of teaching perspectives among academic disciplines. College Teaching Methods \& Styles Journal, 4, 1-8.

Ennis, C.D. \& Chen, A. (1993). Domain specifications and content representativeness of the revised Value Orientation Inventory. Research Quarterly for Exercise and Sport, 64,436-446.

Eisner, E. W. (1992). Curriculum ideologies. In P. W. Jackson (Ed.), Handbook of Research on Curriculum (pp. 302-326). New York: Macmillan.

Fox, D. (1983). Personal theories of teaching. Studies in higher Education, 8(2), 203-220. http://dx.doi.org/10.1080/03075078312331379014

Ha, A.S., Butler, J., Pratt, D. \& Collins, J. (2008). Teaching Games for Understanding: A Study of Hong Kong Prospective Physical Education Teachers' Beliefs, Intentions and Actions in Teaching. Paper presented at the 4th International Conference 2008 - Understanding Games: Enhancing Learning in Teaching and Coaching, Vancouver, Canada, December.

Jarvis-Selinger, S., Collins, J. \& Pratt, D. (2007). Do academic origins influence perspectives on teaching. Teacher Education Quarterly, Summer, 67-81.

Johnson, W. R. (1989). Teachers and teacher training in the twentieth century. In Warren, D. (Ed.). American teachers: histories of a profession at work (pp.237-256). New York: Macmillan.

Kent, S. (2000). Problems of Beginning Teachers: Comparing Graduates of Bachelor's and Master's Level Teacher Preparation Programs. Teacher Educator, 35, 83-96. http://dx.doi.org/10.1080/08878730009555239

McNeil, J. (1990). Curriculum: a comprehensive introduction. Boston Little, Brown.

Pajares, M.P. (1992). Teachers' beliefs and educational research: Cleaning up a messy construct. Review of Educational Research, 62, 307-332. [Online] Available: http://rer.sagepub.com/content/62/3.toc

Pratt, D. (1992). Conceptions of teaching. Adult Education Quarterly, 42(4), 203-220.

Pratt. D. \& Associations. (1998). Five perspectives on teaching in adult and higher education. Malabar, FL: Krieger Publishing Company.

Pratt, D., Collins, J.B. \& Jarvis-Selinger, S.A. (2001). Development and use of the Teaching Perspectives Inventory (TPI). Paper presented at the annual meeting of the American Educational Research Association, Seattle, Washington, April.

Rovegno, I. (2003). Teachers' knowledge construction, In: S. Silverman \& C. Ennis (Eds) Student learning in

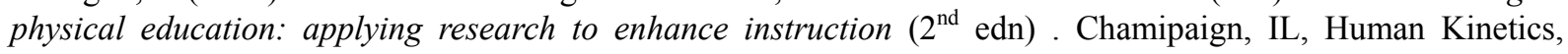
295-310.

Rust, O.F. (1994). The First Year of teaching: It's not what they expected. Teaching and Teacher Education, 10, 205-217. http://dx.doi.org/10.1016/0742-051X(94)90013-2

Shi, W. \& Huang, S. (2006). Views of teaching, teacher, student in university sport under new "compendium". 
Journal of Nanjing Institute of Physical Education. 1, 61-64.

Solmon, M.A. \& Ashy, M.H. (1995). Value orientations of preservice teachers. Research Quarterly for Exercise and Sport, 66, 219-230.

Stran, M. \& Curtner-Smith, D. (2009). Influence of two preservice teachers' value orientations on their interpretation and delivery of sport education. Sport, Education and Society, 14(3), 339-352. [Online] Available: http://www.tandfonline.com/toc/cses20/14/3

Timken, G. \& Mars, H. (2009). The effect of case methods on pre-service physical education teachers' value orientations. Physical Education and Sport Pedagogy, 14(2), 169-187. [Online] Available: http://www.tandfonline.com/toc/cpes20/14/2

Tsangaridou, N. (2008). Trainee primary teachers' beliefs and practices about physical education during student teaching. Physical Education and Sport pedagogy, 13(2), 131-152. [Online] Available: http://www.tandfonline.com/toc/cpes20/13/2

Wang, X. (2004). Transition of PE teachers' teaching and education conception under the new situation of education reform. Journal of Shenyang Institute of Physical Education. 23(5), 702-708.

Xiang, P., Lowy, S. \& McBride, R. (2002). The impact of a field-based elementary physical education methods course on preservice classroom teachers' beliefs. Journal of Teaching in Physical Education, 21, 145-161. [Online] Available: http://journals.humankinetics.com/jtpe-back-issues/JTPEVolume21Issue2January

Table 1. Distribution of teaching perspectives

\begin{tabular}{ccccc}
\hline & \multicolumn{2}{c}{ Dominant perspective } & \multicolumn{2}{c}{ Recessive perspective } \\
\hline Number of dominant perspectives & $\mathrm{N}$ & $\%$ & $\mathrm{~N}$ & $\%$ \\
0 & 16 & $10.2 \%$ & 90 & $56.9 \%$ \\
1 & 62 & $39.2 \%$ & 65 & $41.2 \%$ \\
$2-3$ & 80 & $50.6 \%$ & 3 & $1.9 \%$ \\
Type of teaching perspectives & & & & \\
Transmission & 25 & $15.8 \%$ & 22 & $13.9 \%$ \\
Apprenticeship & 56 & $35.3 \%$ & 3 & $1.9 \%$ \\
Development & 40 & $25.5 \%$ & 12 & $7.6 \%$ \\
Nurturing & 81 & $51.3 \%$ & 9 & $5.7 \%$ \\
Social reform & 22 & $13.9 \%$ & 25 & $15.8 \%$ \\
\hline
\end{tabular}

Table 2. Gender differences of teaching perspectives

\begin{tabular}{cccccc}
\hline & \multicolumn{2}{c}{ Male } & \multicolumn{2}{c}{ Female } \\
& Mean & SD & Mean & SD & $\begin{array}{c}\text { p-value } \\
(\mathrm{p}<.005)\end{array}$ \\
\hline Transmission & 32.75 & 4.01 & 32.85 & 3.76 & 0.95 \\
Apprenticeship & 35.45 & 4.43 & 35.14 & 4.41 & 0.35 \\
Developmental & 32.77 & 4.25 & 32.86 & 5.40 & 0.96 \\
Nurturing & 33.77 & 4.71 & 37.14 & 3.24 & $0.03^{*}$ \\
Social Reform & 32.39 & 5.57 & 32.86 & 3.98 & 0.83 \\
\hline
\end{tabular}

Note. $* \mathrm{p}<0.05, * * \mathrm{p}<0.01$ 
Table 3. Means and SD of Five Perspectives for Four Cohorts of Pre-service Teachers

\begin{tabular}{cccccccccc}
\hline & \multicolumn{2}{c}{$\begin{array}{c}\text { First-year } \\
(\mathrm{N}=)\end{array}$} & \multicolumn{2}{c}{$\begin{array}{c}\text { Second-year } \\
(\mathrm{N}=)\end{array}$} & \multicolumn{2}{c}{$\begin{array}{c}\text { Third-year } \\
(\mathrm{N}=)\end{array}$} & \multicolumn{2}{c}{$\begin{array}{c}\text { Fourth-year } \\
(\mathrm{N}=)\end{array}$} \\
& Mean & SD & Mean & SD & Mean & SD & Mean & SD & $\begin{array}{c}\mathrm{p} \text {-value } \\
(\mathrm{p}<.005)\end{array}$ \\
\hline Transmission & 31.67 & 4.20 & 32.37 & 3.71 & 33.80 & 3.93 & 33.86 & 4.42 & 0.29 \\
Apprenticeship & 32.00 & 5.59 & 34.32 & 3.18 & 34.10 & 4.62 & 33.33 & 5.21 & 0.32 \\
Developmental & 31.67 & 5.03 & 33.05 & 4.41 & 33.20 & 4.29 & 32.57 & 3.92 & 0.61 \\
Nurturing & 31.75 & 4.77 & 35.79 & 3.49 & 34.25 & 5.11 & 34.23 & 3.34 & 0.06 \\
Social Reform & 30.42 & 5.61 & 32.58 & 4.04 & 33.55 & 6.13 & 34.57 & 4.81 & 0.28 \\
\hline
\end{tabular}

Note. ${ }^{*} \mathrm{p}<0.05,{ }^{*} \mathrm{p}<0.01$

Table 4. Intercorrelations between Five Teaching Perspectives for Pre-service Teachers

\begin{tabular}{cccccc}
\hline $\begin{array}{c}\text { Teaching } \\
\text { perspectives }\end{array}$ & Transmission & Apprenticeship & Development & Nurturing & Social Reform \\
\hline Transmission & - & 0.15 & 0.09 & 0.04 & 0.14 \\
Apprenticeship & - & - & $0.34^{*}$ & 0.08 & $0.77^{* *}$ \\
Development & & - & $0.61^{* *}$ & 0.05 \\
Nurturing & & & - & 0.12 \\
Social Reform & & & & & - \\
\hline
\end{tabular}

Note. ${ }^{*} \mathrm{p}<0.05,{ }^{*} \mathrm{p}<0.01$ 